\title{
In memory of Associate Professor Teresa Kozanecka (1946-2020)
}

\author{
Józef Chojnicki \\ Warsaw University of Life Sciences - SGGW, Institute of Agriculture, Department of Soil Science, 159 Nowoursynowska Str., 02-776 Warsaw, \\ Poland \\ * e-mail: jozef_chojnicki@sggw.edu.pl
}

On 7 November 2020 Associate Professor Teresa Kozanecka passed away at the age of 74 . In 1973 she obtained the title of Master of Science in Agriculture at the Faculty of Agriculture of the Warsaw University of Life Sciences-SGGW (WULS-SGGW) and in 1979 she started research and teaching at the Department of Soil Science at the WULS-SGGW. Her entire professional life was associated with the WULS-SGGW. She obtained the PhD of agricultural sciences in 1985 on the basis of dissertation "Physicochemical properties of the soil in an apple orchard depending on many years of diversified mineral fertilization" made under the supervision of Professor Marian Kępka and was habilitated in 2004 after submission of

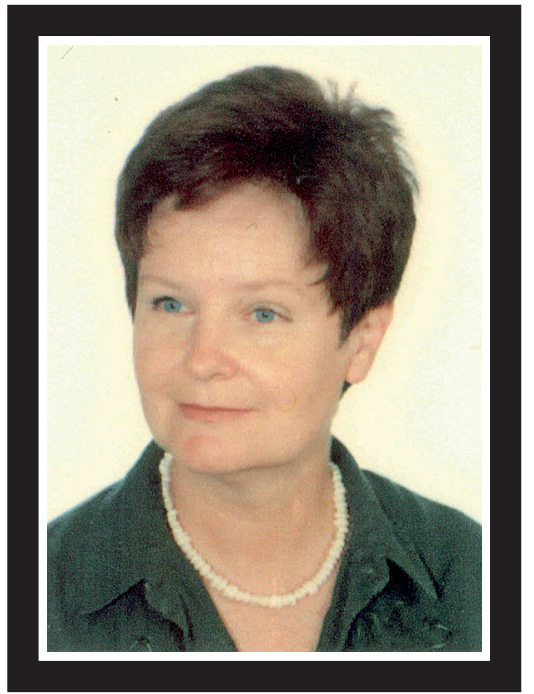

dents and engineers in the agriculture field of study. Under her supervision, 1 doctoral dissertation, 14 master's and 12 engineering theses were carried out.

Professor's Kozanecka was involved in organizational work. She was the tutor of the student, internship students and students of the Chemical Technical School, participated in the work of various committees, organization of seminars and scientific conferences at the Faculty of Agriculture and Biology. She participated in the development and promotion of soil science, performing various functions in the Warsaw Branch of Soil Science Society of Poland. For achievements, she was awarded, among others: the Gold Medal for Long Service, the Golden Badge of the the dissertation "Influence of soil and climatic conditions and cultivars on the ionic state of apple leaves". In 2009 she received the position of associate professor.

Professor's scientific activity was mainly focused on the study of the impact of fertilization, cultivation method on the physicochemical, chemical and biological properties of soils in orchards, the ionic state of apple leaves and other trees depending on soil and climatic conditions. She also studied heavy metal pollution of urban, arable, forest soils and plant, and the possibilities of using algae, lichens and mosses to assess anthropopressure on the environment. As an author or co-author, she published 73 scientific papers, including 44 reviewed papers (some of them are listed below) and participated in the elaboration of 6 different expertise, project work, and soil mapping. She was the manager of one research project financed by the Ministry of Science and Higher Education and a co-contractor in 2 such projects.

She conducted lectures, laboratory and field exercises of soil science at full-time and part-time studies in the field of landscape architecture, horticulture, biology, agriculture, and faculties in the subject of soil fertility and productivity, bioindication and environmental monitoring in the field of agriculture. Also pursued diploma seminars for graduate stu-
Soil Science Society of Poland and awarded with the award of the Rector of the WULS-SGGW for achievements in the field of scientific research.

Professor's Kozanecka fulfilled her life with dignity, working hard as a man and an academic teacher, skillfully combining scientific work with the dedication and commitment of her family. She was a very kind person, friendly and open to other people, creating very positive relationships with colleagues in research work and with students in the teaching process. The memory of her, as a valuable and disinterested person, an inquisitive researcher, will forever remain in the academic community of the Warsaw University of Life Sciences in Warsaw.

The most important scientific articles published by Professor Teresa Kozanecka are listed below. The articles marked with the letters PL were published in Polish language with abstracts and summaries in English.

1. Kwasowski W., Kozanecka T., Górska E., Gozdowski D., Kowalczyk P., 2016. Application of heavy metals in street dust in the monitoring of changes in environment. Fresenius Environmental Bulletin Vol. 25, 1: 103-112. 
2. Kozanecka T., Brogowski Z., Kisiel M., Stępień W., 2011. Ruchliwość anionów w glebach z wieloletnich doświadczeń nawozowych w Skierniewicach. Zeszyty Problemowe Postępów Nauk Rolniczych 565: 163-173.

3. Kozanecka T., Kazem-Bek A., Czarnowska K., Kwasowski W., 2010. Application of algae and lichens in the monitoring of changes in the natural environment. Fresenius Environmental Bulletin Vol. 19, 4: 553-557.

4. Kwasowski W., Kozanecka T., 2010. Evaluation of the content of zinc and lead in selected vegetative organs of potatoes (Solanum tuberosum) growing in the vicinity of the Warszawa-Poznań speedway. Fresenius Environmental Bulletin Vol. 19, 2a: 378-382.

5. Brogowski Z., Kozanecka T., 2009. Impact of certain genetic horizons of soil on the yield and chemical composition of westerwold ryegrass (Arrhenatherum elatius L.). Polish Journal of Soil Science 42, 1: 77-88.

6. Kozanecka T., Brogowski Z., Kisiel M., Stępień W., 2009. Mobility of exchangeble cations in soils from long term field experiments in Skierniewice. Polish Journal of Soil Science 42, 1: 1-14.

7. Kazem-Bek A., Kozanecka T., 2007. Porosty i ich rola w środowisku przyrodniczym. Cz. 1. Charakterystyka, występowanie i zastosowanie porostów. Ochrona Środowiska i Zasobów Naturalnych 32: 61-67.

8. Kazem-Bek A., Kozanecka T., 2007. Porosty i ich rola w środowisku przyrodniczym. Cz. 2. Zawartość makro-i mikroskładników. Ochrona Środowiska i Zasobów Naturalnych 32: 68-75.

9. Kozanecka T., Czarnowska K., Łaszczych K., 2007. Zawartość pierwiastków śladowych w pyle drogowym z trasy Zegrze - Mrągowo. Ochrona Środowiska i Zasobów Naturalnych 32: 140-144.

10. Kozanecka T., Czarnowska K., Brogowski Z., Kwasowski W., 2006. Content of microelements in selected herbs from natural meadows. Polish Journal of Environmental Studies 15, 2a, P. 2: 385-389.

11. Kwasowski W., Michalak D., Kozanecka T., 2006. Bioaccumulation of microelements in selected plants of the undergrowth in Kampinos National Park. Polish Journal of Environmental Studies 15, 2a, P. 2: 398-402.

12. Kozanecka T., 2003. Influence of soil and climatic conditions and cultivars on the ionic state of apple leaves. Rozprawy - SGGW, Warszawa, s. 80.

13. Kozanecka T., Czarnowska K., Jaworska A., 2003. Content of heavy metals in road coarse dust of Warsaw environs. Roczniki Gleboznawcze - Soil Science Annual 54(3): 73-78. (PL)

14. Czarnowska K., Kozanecka T., 2003. Accumulation of $\mathrm{Zn}, \mathrm{Pb}, \mathrm{Cu}$ and $\mathrm{Cd}$ in anthropogenic soils of Warsaw. Roczniki Gleboznawcze - Soil Science Annual 54(4): 77-81. (PL)

15. Kozanecka T., Chojnicki J., Kwasowski W., 2002. Content of heavy metals in plant from pollution-free regions. Polish Journal of Environmental Studies 11, 4:`395-399.
16. Brogowski Z., Gawrońska-Kulesza A., Kozanecka T., 2002. Red clover as a receptor of $\mathrm{CO}_{2}$ from the atmosphere and some compounds from soil. Polish Journal of Environmental Studies 11, 6: 625-629.

17. Czarnowska K., Chlibiuk M., Kozanecka T., 2002. Trace elements in arable soils near roads around of Warsaw. Roczniki Gleboznawcze - Soil Science Annual 53(3/4): 67-74. (PL)

18. Czarnowska K., Kozanecka T., 2001. Soluble forms of heavy metals in anthropogenic soils of Warsaw area. Roczniki Gleboznawcze - Soil Science Annual 52(3/4): 45-51. (PL)

19. Kozanecka T., Czarnowska K., Kwasowski W., 2000. Accumulation of heavy metals in the soils near petrol stations in Warsaw. Roczniki Gleboznawcze - Soil Science Annual 51(1/2): 73-78. (PL)

20. Kwasowski W., Chojnicki J., Okołowicz M., Kozanecka T., 2000. Heavy metals content in standard soil plots of the Puszcza Biała Forest. Roczniki Gleboznawcze - Soil Science Annual 51(3/4): 85-95. (PL)

21. Kozanecka T., Zagórski Z., Scherer H.W., 2000. The contents of nonexchangeable ammonium in rendzina soils. Roczniki Gleboznawcze - Soil Science Annual 51(3/4): 77-83. (PL)

22. Kozanecka T., Chojnicki J., 1998. Manganese available and soluble in $20 \% \mathrm{HCl}$ in lessive soil of apple orchard. Roczniki Gleboznawcze - Soil Science Annual 49(3/4): 41-49. (PL)

23. Kozanecka T., Scherer H.W., 1996. The influence of nitrogen and potassium fertilization and the soil management system in apple orchard on the content of nonexchangeable $\mathrm{NH}_{4}-\mathrm{N}$ in soil. Roczniki Gleboznawcze - Soil Science Annual 47(1/2): 55-64. (PL)

24. Kozanecka T., Rekosz-Burlaga H., Russel S., 1996. Effect of apple orchard soil management system, liming and nitrogen fertilization in biological activity. Roczniki Gleboznawcze - Soil Science Annual 47(supl.): 75-84. (PL)

25. Kozanecka T., Kępka M., 1996. Influence of agro-ecological factors on physico-chemical properties of the soil of apple orchard. Roczniki Gleboznawcze - Soil Science Annual 47(supl.): 23-30. (PL)

26. Kozanecka T., 1995. Contents of $\mathrm{N}-\mathrm{NH}_{4}$ and $\mathrm{N}-\mathrm{NO}_{3}$ mineral forms of nitrogen in soil of apple orchard. Roczniki Gleboznawcze - Soil Science Annual 46(1/2): 105-117. (PL)

27. Kozanecka T., Kępka M., Sadowski A., 1989. Chemical properties of soil in an apple orchard depending on liming, soil management system and nitrogen and potassium fertilization. Roczniki Gleboznawcze - Soil Science Annual 40(1): 53-65. (PL)

28. Kozanecka T., Kępka M., Ścibisz K., 1988. Effect of the nitrogen and potassium fertilization and of the soil tending system on the manganese content in soil and apple leaves. Roczniki Gleboznawcze - Soil Science Annual 39(3): 257-259. (PL)

29. Czarnowska K., Gworek B., Kozanecka T., 1983. The content of heavy metals in the soils and moss of the Kampinos National Park. (In:) Wpływ działalności człowieka na środowisko glebowe w Kampinoskim Parku Narodowym, Wyd. SGGW-AR, Warszawa: 123-137. (PL) 


\section{Wspomnienie dr hab. Teresy Kozaneckiej prof. SGGW (1946-2020)}

W dniu 7 listopada 2020 roku w wieku 74 lat zmarła dr hab. Teresa Kozanecka prof. nadzwyczajny SGGW. Studia na Wydziale Rolniczym Szkoły Głównej Gospodarstwa Wiejskiego (SGGW) ukończyła w 1973 roku uzyskując tytuł magistra inżyniera rolnictwa, a w roku 1979 rozpoczęła pracę naukową i dydaktyczną w Katedrze Gleboznawstwa Szkoły Głównej Gospodarstwa Wiejskiego. Całe swoje życie zawodowe związała z SGGW kolejno uzyskując: stopień doktora nauk rolniczych w 1985 r. na podstawie pracy „Właściwości fizykochemiczne gleby w sadzie jabłoniowym $w$ zależności od wieloletniego, zróżnicowanego nawożenia mineralnego" wykonanej pod kierunkiem prof. dr hab. Mariana Kępki, doktora habilitowanego w 2004 r. po przedłożeniu rozprawy pt. „Wpływ warunków glebowo-siedliskowych i odmiany na stan jonowy liści jabłoni” oraz stanowisko profesora nadzwyczajnego SGGW w $2009 \mathrm{r}$.

Działalność naukowa Pani Doktor skupiała się przede wszystkim na badaniu wpływu nawożenia, sposobu uprawy na właściwości fizykochemiczne, chemiczne, biologiczne gleb w sadach, stanu jonowego liści jabłoni i innych drzew w zależności od warunków glebowo-klimatycznych, zanieczyszczenia metalami ciężkimi gleb miejskich, uprawnych, leśnych i roślin oraz możliwościach wykorzystania glonów, porostów i mchów do oceny antropopresji na środowisko przyrodnicze. Opublikowała jako autor lub współautor 73 prace naukowe, w tym 44 prace recenzowane oraz uczestniczyła w 6 opracowaniach o charakterze ekspertyz, prac projektowych i kartograficznych. Była kierownikiem jednego projektu badawczego finansowanego przez MNISW a w 2 projektach była współwykonawcą.

Prowadziła wykłady, ćwiczenia laboratoryjne i terenowe z przedmiotu gleboznawstwo na studiach stacjonarnych i niestacjonarnych kierunku architektury krajobrazu, ogrodnictwa, biologii, rolnictwa oraz fakultety z przedmiotu żyzność i produktywność gleb, bioindykacja i monitoring środowiska na kierunku rolnictwo. Realizowała również seminaria dyplomowe dla magistrantów i inżynierów na kierunku studiów rolnictwo. Pod jej kierunkiem wykonano 1 pracę doktorską, 14 prac magisterskich i 12 prac inżynierskich.

Poza działalnością naukową i dydaktyczną dr hab. Teresa Kozanecka była zaangażowana w prace organizacyjne. Pełniła funkcję opiekuna roku studentów, praktyk studentów i uczniów Technikum Chemicznego, brała udział w pracach różnych komisji, organizacji seminariów i konferencji naukowych na Wydziale Rolnictwa i Biologii. Uczestniczyła w rozwoju i promocji gleboznawstwa, pełniąc różne funkcje w Oddziale Warszawskim Polskiego Towarzystwa Gleboznawczego. Za całokształt osiągnięć została odznaczona m. in.: Medalem Złotym za Długoletnią Służbę, Złotą Odznaką Polskiego Towarzystwa Gleboznawczego oraz wyróżniona nagrodą JM Rektora SGGW za osiągnięcia w dziedzinie badań naukowych.

Dr hab. Teresa Kozanecka swoje 74-letnie życie wypełniła godnie, pracowicie jako człowiek i nauczyciel akademicki, umiejętnie godząc pracę naukową z dużym oddaniem i zaangażowaniem swojej rodziny. Odeszła od nas osoba bardzo życzliwa, koleżeńska i otwarta na innego człowieka, tworząca bardzo pozytywne relacje ze współpracownikami w pracy naukowej i studentami procesie nauczania. Pamięć o Niej, jako wartościowym i bezinteresownym człowieku, dociekliwym badaczu pozostanie na zawsze w społeczności akademickiej Szkoły Głównej Gospodarstwa Wiejskiego w Warszawie. 